\title{
Ponderosa pine aboveground growth after cattle removal of terminal tissue
}

\author{
MICHAEL G. "SHERM” KARL AND PAUL S. DOESCHER
}

Authors are rangeland management specialist-ecologist, Interior Columbia Basin Ecosystem Management Project, USDA-Forest Service, Walla Walla, Wash. 99362; and professor, Department of Rangeland Resources, Oregon State University, Corvallis, Ore. 97331. At the time of the research, the senior author was graduate research assistant, Department of Rangeland Resources, Oregon State University, Corvallis, Ore.

Abstract

Mismanagement of livestock can result in herbivory on Pinus seedlings with potential for growth loss. From 1986 to 1990 on a conifer plantation in the Mixed-Conifer Zone of southwestern Oregon we measured the aboveground growth of ponderosa pine (Pinus ponderosa Douglas ex Lawson \& C. Lawson var. ponderosa) seedlings that had sustained (1) removal of terminal stem or bud tissue by cattle, and (2) no removal (control). In 1990 (year 5 of the plantation), cumulative, absolute height and stem volume on seedlings that sustained terminal tissue removal were similar to control seedlings. In 1988, relative height growth was comparable between control seedlings and seedlings sustaining tissue removal in May 1987 . In contrast, 1988 relative height growth was $-22 \%(\mathrm{P}<0.05)$ for seedlings sustaining tissue removal in August 1987, compared with control seedlings. Relative stem volume growth in 1988 ranged from -21 to $-26 \%$ $(P<0.05)$ for seedlings sustaining tissue removal in (1) August 1987, (2) April or May 1988, and (3) 1987 and 1988, compared with control seedlings. Reduced relative growth was short-term. Relative growth rates for seedlings sustaining tissue removal were comparable to control by the first or second year after removal. Seedlings sustaining tissue removal before winter bud set (April and May) were more likely to recover by the first year than seedlings sustaining tissue removal after winter bud set (August). We propose that if silviculturists prescribe cattle grazing early in the growing season and terminal tissue is removed at that time, they can still achieve understory vegetation control and enhanced soil water availability without jeopardizing longterm aboveground growth of ponderosa pine. The lack of spatial replication of treatments (terminal tissue removal dates) limits spatial extrapolation of our findings. The credibility of our findings should be tested with additional research on the growth response of ponderosa pine seedlings subsequent to actual livestock herbivory, conducted with spatially replicated treatments.

Key Words: forest grazing, Pinus ponderosa, conifer seedling growth, relative growth rate, height growth, stem volume growth

Rescarch was financed by the USDI-BLM, Medford District, Medford, Ore. We thank M. Jabbes, P. Halvorson, N. Abu Bakar, and A. Law for field assistance, and R.G. Petersen and B.W. Knapp for statistical consultation. Constructive reviews were provided by R.A. Bellows, M.R. Haferkamp, R.K. Heitschmidt, S.D. Tesch, and several anonymous reviewers. This article is submitted as Technical Paper No. 11147, Oregon Agricultural Experiment Station, Corvallis, Ore.

Manuscript accepted 11 Feb. 1997.

\section{Resumen}

El mal manejo de ganado puede resultar en herbivorio en planta de semillero de Pinus con la capacidad de pérdida de crecimiento. De 1986 a 1990 en una plantación de conífero en la Zona Conífera-Mixta del sudoeste de Oregon medimos el crecimiento sobre tierra de planta de semillero del pino Ponderosa (Pinus ponderosa Douglas ex Lawson \& C. Lawson var. ponderosa) que sufrieron (1) removimiento por ganado del tallo terminal o de tejido del botón y (2) sin removimiento (control). En 1990 (año 5 de la plantación), cumulativamente, altura absoluta y volumen del tallo en plantas de semillero que sostenieron remoción de tejido terminal fueron similar a plantas de semillero de control. En 1988, el relativo crecimiento de altura fue comparable entre plantas de semillero de control y plantas de semillero sufriendo removimiento de tejido en mayo 1987 . En contraste, el crecimiento de altura relativo fue $-\mathbf{2 2 \%}(\mathbf{P}<\mathbf{0 . 0 5})$ para plantas de semilero sufriendo removimiento de tejido en agosto 1987, comparado con plantas de semillero de control. El ralativo crecimiento de volumen del tallo en 1988 fue de -21 a $-26 \%(\mathrm{P}<0.05)$ para plantas de semillero sufriendo removimiento de tejido en (1) agosto 1987, (2) abril o mayo 1988, y (3) 1987 y 1988 comparado con plantas de semillero de control. Reducción de crecimiento relativo fue de termino corto. Grados de crecimiento relativo para plantas de semillero sufriendo removimiento de tejido fueron comparables con las de control para el primer o segundo año despues de removimiento. Plantas de semillero sufriendo removimiento de tejido antes de botónes de invierno (abril y mayo) tuvieron mayor posibilidad de recuperar para el primer año que plantas que sufrieron removimiento de tejido despues de retoño de invierno (agosto). Proponemos que si silvicultores prescriben apacentar el ganado temprano en la tempo rada de crecimiento y tejido terminal es removido en ese tiempo, pueden an obtener control de vegetación que crece serca al suelo y encarecer la eficacia de agua en la tierra sin ariesgar crecimiento de termino largo sobre tierra del pino ponderosa. La falta de replicación espacial de tratamientos (fechas de removimiento de tejido terminal) limita extrapolación espacial de nuestros descubrimientos. La credibilidad de nuestros descubrimientos debe ser puesto a prueba con investigación adicional sobre la respuesta de crecimiento de plantas de semillero del pino ponderosa subsequente al apacento actual de ganado, conducido con tratamientos replicados espacialmente. 
Grazing by livestock is practiced in forests characterized by open stands of Pinus because palatable forage is available for livestock consumption. Mismanagement of livestock can result in herbivory on Pinus seedlings. Herbivory apparently retards aboveground growth and if severe, kills seedlings (Hill 1917, Sparhawk 1918, Cooperrider 1938, Cassady et al. 1955). The underlying tenet in Hill (1917), Sparhawk (1918), Cassady et al. (1955), and others since, has been that growth loss is unrecoverable during the tree's lifespan, which results in longer duration harvest rotations and loss of timber revenue. To prevent growth loss or browsing and trampling damage from livestock, Cassady et al. (1955), Rindt (1965), and Adams (1975) recommend deferment of livestock grazing until pine seedlings exceed browse height.

Herbivory and its consequences regarding aboveground growth of Pinus seedlings often is simulated by clipping (Craighead 1940; Bruce 1956; Kulman 1965; Hughes 1976; Ericsson et al. 1980; Lewis 1980a, 1980b; Neilsen 1981; Britton 1988; Edenius et al. 1993; Sanchez-Martinez and Wagner 1994). To our knowledge, detailed growth measurements of Pinus seedlings subsequent to actual hetbivory by livestock have not been reported. Assessments of seedling growth responses to herbivory are imprecise and lack predictability (Lewis 1980a), presumably because variable amounts of tissue are removed and seedlings sustaining herbivory vary in age and physiological status. Nevertheless, investigations of herbivory and its effects on aboveground growth of conifer seedlings are pertinent to coordinated management and production of livestock and timber. Our objective was to document the aboveground growth of same-aged, ponderosa pine (Pinus ponderosa Douglas ex Lawson \& C. Lawson var. ponderosa) seedlings that had sustained (1) removal of terminal stem or bud tissue by cattle, and (2) no removal, to ascertain the timing and magnitude of the growth response subsequent to terminal tissue removal by cattle. Terminal tissue removal by cattle was an unplanned outcome of our overall research (investigating prescribed cattle grazing as a silvicultural tool on conifer plantations). Terminal tissue removal by cattle occurred on only 1 site and thus treatments and growth responses were not spatially replicated. This is a case study of growth response of ponderosa pine seedlings to terminal tissue removal by cattle.

\section{Methods}

\section{Study Site and Prescribed Cattle Grazing}

We conducted this study from 1986-1990 on a 5-ha portion of Sugar Pine Flat $\left(122^{\circ} 40^{\prime} \mathrm{W} 42^{\circ} 35^{\prime} \mathrm{N}\right.$; elevation $\left.=670 \mathrm{~m}\right)$ located $8.5 \mathrm{~km}$ northwest of Butte Falls, Ore., on public land administered by the Medford District of the USDI-BLM. Soils are fine, mixed, mesic Ultic Haploxeralfs of the Freezener series with a solum typically 1-1.5 m thick (Johnson 1993). The MixedConifer Zone typifies midelevations in the southwestem Oregon Cascade Range (Franklin and Dymess 1973) and characterized the vegetation on Sugar Pine Flat. Major forest tree species of this zone include Douglas-fir (Pseudotsuga menziesii [Mirbel] Franco), ponderosa pine, sugar pine (Pinus lambertiana Douglas), incense-cedar (Libocedrus decurrens [Torrey] Florin), and white fir (Abies concolor [Gordon \& Glendinning] Hildebrand). These species existed on the study site before tree harvest. The study site was representative of low-elevation forested lands in the interior of southwestern Oregon, lands that have historically been difficult to reforest (Tesch et al. 1990) because of aridity.
Climate is Mediterranean with cool, wet winters and hot, dry summers. Annual precipitation during 1986-1989 at the Lost Creek Dam weather station located about $9 \mathrm{~km}$ NNW of Sugar Pine Flat ranged from 708 to $829 \mathrm{~mm}$, below the 1960-1980 average of 889 $\mathrm{mm}$ (Froehlich et al. 1982). Dry season (1 May to 30 September) precipitation at the Lost Creek Dam weathcr station was above the 1960-1980 average of $127 \mathrm{~mm}$ (McNabb et al. 1982) in 1986 (166 $\mathrm{mm}$ ), 1989 (154 mm), and 1990 (152 mm for May-August), below average in $1987(102 \mathrm{~mm})$, and average in $1988(126 \mathrm{~mm})$. The frost-free season ranges from 100 to 120 days.

A 14.5-ha portion of Sugar Pine Flat, including the 5-ha study site, was clear-cut and tractor-logged in July 1985. The clear-cut was prepared in early September 1985 for tree planting by ripping soil to ameliorate compaction, and burning slash piles. A mix of herbaccous species [see Karl and Doescher (1993) for seeding rates and species] was planted on 8 ha (which included the 5-ha study site) with hand seeders immediately after site preparation. In early March 1986, 2-0, bare-root seedlings of Douglas-fir and ponderosa pine (mean height $20.3 \mathrm{~cm}$ and stem diameter $5 \mathrm{~mm}$ ) were planted in pairs (pair $=1$ of each species) across the clear-cut at a density of about $1,400 \mathrm{ha}^{-1}$ (i.e. $2.7 \times 2.7$ $\mathrm{m}$ spacing). Seedlings were grown at the J. Hubert Stone Forest Service Nursery near Medford, Ore. and were lifted in January 1986. Seed was collected at an elevation of about $900 \mathrm{~m}$ from tree seed zone 502 of subzone B (Butte Falls).

Prescribed cattle grazing was applied on the study site. Prescribed cattle grazing was used as a method for control of competing vegetation. We initiated grazing in late May 1986, about 8 months after seeding and nearly 3 months after tree planting. In 1987-1990, grazing was initiated by mid April to early May when aboveground standing crop exceeded roughly $500 \mathrm{~kg} \mathrm{ha}^{-1}$, and before orchardgrass (Dactylis glomerata L.) and perennial ryegrass (Lolium perenne L.) (seeded species) exserted inflorescences. Subsequent regrowth necessitated additional grazing applications. Put-and-take grazing (Wheeler et al. 1973) was practiced. Cattle were removed when forage height was reduced to about $5 \mathrm{~cm}$ or shortly after tissue removal on conifer seedlings was observed.

\section{Field Sampling and Data Analyses}

We established 15 permanently marked circular plots on the study site in a systematic manner (5 each on 3 parallel line transects) in 1986 before cattle grazing was initiated. Plot sizes were about 0.02 ha ( $8 \mathrm{~m}$ radius). Plots were positioned a minimum 30 $m$ distance from the forest edge (perimeter of clear-cut) to prevent edge effect and ensure uniform insolation of conifer seedlings.

Aboveground growth data were collected from ponderosa pine seedlings in late September in each of the years 1986 through 1990. Seedlings included in the plots totalled 194 at planting time, varying between 9 and 16 per plot. Of the 194 seedlings, those that had sustained damage from trampling or porcupine girdling were excluded from analyses. Seedlings included in analyses were placed into 6 treatment groups reflecting their history of terminal tissue removal. Control seedlings were those with no history of ungulate (domestic or native) removal of terminal stem or bud tissue. Control seedlings were selected by default (i.e. seedlings unprotected from browsing by cattle but nevertheless did not sustain terminal tissue removal by cattle). This was admittedly an atypical manner of selecting controls, resulting from terminal tissue removal by cattle which we were attempting to preclude, rather than encourage. Remaining 
seedlings were placed into 5 groups characterized by the timing of cattle removal of terminal stem or bud tissue. These 5 groups were (1) May 1987, (2) August 1987, (3) April or May 1988, (4) May and/or August 1987 and April or May 1988, and (5) May and/or August 1987 and April or May 1989. We use the term removal rather than herbivory because inadvertent cattle breakage of elongating terminal buds occurred in addition to actual browsing. We use the term removal rather than defoliation because stem tissue was removed in addition to needles.

We measured seedling height in $\mathrm{cm}$ at the highest position on the seedling (typically the tip of terminal bud on terminal or lateral shoot). We measured stem diameter to the nearest $0.01 \mathrm{~mm}$ with an electronic digital caliper at a position $1-2 \mathrm{~cm}$ above the soil surface. If cattle removal of terminal tissue resulted in a negative increment for annual height growth (seedling height at late September of year $t+1$ less than height at late September of year $t$ ), we recorded the actual negative value (instead of zero) to preclude biased height estimates. We precluded biased estimates of stem diameter of scarred stems (with attendant swelling) by measuring stem diameter above the swelling. Seedling stem volume (SV, $\mathrm{cm}^{3}$ ) was calculated using the formula for a right circular cone:

$$
\mathrm{SV}=0.262 \times \text { (stem diameter })^{2} \times \text { total height. }
$$

We computed mean relative growth rates and utilized them in addition to absolute growth rates to elucidate the timing and degree of growth recovery of seedlings subjected to terminal tissue removal by cattle. Annual, mean relative growth rates (RGR; Radford 1967) were calculated for height (1987-1990) using September height measurements from 1986-1990, and for stem volume (1988-1990) using September height and stem diameter measurcments from 1987-1990. We were unable to estimate stem volume RGR for 1987 because stem diameter was not recorded in September 1986 for all seedlings.

Absolute and relative height and stem volume data were analyzed using a repeated measures ANOVA for a completely randomized design. Timing of terminal tissue removal (treatments) and year were main effects with year being the repeated measures factor. Treatments were not spatially replicated; we were prevented from adequately replicating treatments because treatments were dependent on cattle behavior, in this instance, behavior that we were attempting to prevent rather than encourage. As mentioned previously, the removal of terminal stem or bud tissue on ponderosa pine seedlings was an unplanned outcome of our overall research, but the tissue removal events provided the opportunity to investigate aboveground growth response of seedlings subsequent to actual cattle browsing.

To satisfy homoscedasticity assumptions of ANOVA, data sets were square root transformed after the Bartlett test for homogeneity of variance detected heteroscedasticity. Upon detection of significant treatment by year interactions, 'a priori' treatment comparisons within year were restricted to include only the terminal tissue removal dates vs the control. The Dunnett procedure was used for treatment mean separation. Significance tests and mean separation tests were performed at an alpha level of $\mathrm{P}=0.05$ and only significant differences were interpreted.

\section{Results}

Cattle removed terminal tissue on a substantial percentage of seedlings in May and August 1987 (Table 1). Tissue removal in
Table 1. Percent of ponderosa pine seedlings sustaining terminal tissue (needle, stem, bud, or combination thereof) removal by cattle on the study site in 1986-1989. Tissue removal in 1988 and 1989 included terminal bud breakage by cattle. Month refers to times each year when seedlings were observed for tissue removal. Except for early September 1986, seedlings were observed immediately after cattle removal from the study site.

\begin{tabular}{lcc}
\hline \hline Year & Month & Percent \\
\hline 1986 & Early Sep. & 6 \\
& Late Sep. & 0 \\
1987 & May & 29 \\
& Jul. & 0 \\
& Aug. & 85 \\
1988 & Apr. & 15 \\
& May & 5 \\
& Jun. & 2 \\
1989 & May & 8 \\
& Jun. & 0 \\
& Jul. & 0 \\
\hline
\end{tabular}

${ }^{1}$ Cattle grazing event occurred in late May 1986. Authors were not available until early September to collect observations.

May and August was restricted mostly to periods when salt and trace mineral were not provided. August tissue removal was severe, as both current-year needles and stem tissue were consumed. Tissue removal in 1988 and 1989 consisted mostly of inadvertent cattle breakage of elongating terminal buds. By 1989 , terminal buds of most seedlings exceeded the height at which cattle breakage was likely.

\section{Height Growth}

Cattle removal of terminal stem or bud tissue failed to produce a cumulative loss of seedling height growth compared with control seedlings (Table 2). Average heights in 1990 for seedlings that sustained tissue removal varied from 111 to $146 \mathrm{~cm}$, whereas average height of the control group was $115 \mathrm{~cm}$. Height of seedlings sustaining tissue removal in April-May 1988 was $27 \%$ greater than control seedlings in 1989 and 1990.

\section{Stem Volume Growth}

Cattle removal of terminal stem or bud tissue failed to produce a cumulative loss of seedling stem volume growth compared with control seedlings (Table 2). Average stem volumes in 1990 (untransformed raw data) for seedlings that sustained tissue removal varied from about 550 to $1,110 \mathrm{~cm}^{3}$ whereas average stem volume of control seedlings was about $710 \mathrm{~cm}^{3}$. Stem volume of seedlings sustaining tissue removal in April-May 1988 was $68 \%$ and $56 \%$ greater than control seedlings in 1989 and 1990, respectively (as also noted for height).

\section{Relative Height and Stem Volume Growth}

Seedlings sustaining tissue removal in April-May 1988 had $50 \%$ greater height RGR in the previous year (1987) compared with control seedlings (Table 2). Height RGR in 1988 of seedlings sustaining tissue removal in August 1987 was depressed $(-22 \%)$ compared with control seedlings, whereas height RGR in 1988 of those sustaining tissue removal in May 1987 was comparable to control seedlings. Depressed growth was short-term because subsequent relative height growth in 1989 and 1990 was comparable between seedlings sustaining tissue removal in August 1987 and control seedlings. By 1990, 
Table 2. Aboveground growth of control seedlings $(n=36$ ), and seedlings sustaining terminal stem or bud tissue removal in either $M a y ~ 1987$ ( $=15$ ), Aug. 1987 ( $n=56$ ), Apr.-May $1988(n=14), 1987$ and $1988(n=15)$, or 1987 and $1989(n=7)$. Standard errors are in parentheses. Values for stem volume and stem volume $R G R$ represent back-transformed means and standard errors.

\begin{tabular}{|c|c|c|c|c|c|c|}
\hline Year & Control & May 1987 & Aug. 1987 & Apr.-May 1988 & 1987 and 1988 & 1987 and 1989 \\
\hline \multicolumn{7}{|c|}{ Height $(\mathrm{cm})$} \\
\hline 1986 & $25(1.1)$ & $26(2.3)$ & $26(0.8)$ & $29(1.9)$ & $26(1.3)$ & $25(2.6)$ \\
\hline 1987 & $36(1.7)$ & $34(3.4)$ & $36(1.3)$ & $50(2.3)$ & $36(1.9)$ & $37(3.9)$ \\
\hline 1988 & $55(2.8)$ & $51(4.8)$ & $51(2.0)$ & $69(3.3)$ & $52(3.8)$ & $57(5.9)$ \\
\hline 1989 & $77(4.0)$ & $74(6.9)$ & $74(2.9)$ & $98(4.5)^{*}$ & $80(6.5)$ & $79(6.0)$ \\
\hline 1990 & $115(5.8)$ & $112(8.7)$ & $111(4.1)$ & $146(7.2)^{*}$ & $122(9.9)$ & $125(10.0)$ \\
\hline \multicolumn{7}{|c|}{ Height RGR (cm cm$\left.{ }^{-1} \mathrm{yr}^{-1}\right)$} \\
\hline 1987 & $0.37(0.029)$ & $0.27(0.050)$ & $0.32(0.026)$ & $0.56(0.050)^{*}$ & $0.32(0.048)$ & $0.40(0.099)$ \\
\hline 1988 & $0.43(0.032)$ & $0.41(0.048)$ & $0.34(0.021)^{*}$ & $0.32(0.30)$ & $0.33(0.051)$ & $0.43(0.046)$ \\
\hline 1989 & $0.33(0.016)$ & $0.38(0.030)$ & $0.36(0.011)$ & $0.35(0.028)$ & $0.43(0.040)$ & $0.34(0.048)$ \\
\hline 1990 & $0.40(0.016)$ & $0.43(0.024)$ & $0.41(0.013)$ & $0.40(0.022)$ & $0.41(0.024)$ & $0.45(0.030)$ \\
\hline \multicolumn{7}{|c|}{ Stem Volume $\left(\mathrm{cm}^{3}\right)$} \\
\hline 1987 & $16(0.06)$ & $18(0.4)$ & $18(0.04)$ & $44(0.1)$ & $22(0.1)$ & $24(0.2)$ \\
\hline 1988 & $55(0.3)$ & $49(1.0)$ & $47(0.1)$ & $107(0.5)$ & $54(0.5)$ & $70(0.9)$ \\
\hline 1989 & $194(1.0)$ & $172(3.5)$ & $155(0.4)$ & $363(1.5)^{*}$ & $198(1.9)$ & $215(1.8)$ \\
\hline 1990 & $604(3.0)$ & $530(8.1)$ & $486(1.2)$ & $1,066(3.6)^{*}$ & $577(5.7)$ & $662(6.0)$ \\
\hline \multicolumn{7}{|c|}{ Stem Volume RGR $\left(\mathrm{cm}^{3} \mathrm{~cm}^{-3} \mathrm{yr}^{-1}\right)$} \\
\hline 1988 & $1.14(0.001)$ & $0.94(0.004)$ & $0.90(0.001)^{*}$ & $0.85(0.002)^{*}$ & $0.79(0.006)^{*}$ & $1.00(0.003)$ \\
\hline 1989 & $1.24(0.0004)$ & $1.26(0.0005)$ & $1.18(0.0002)$ & $1.21(0.001)$ & $1.28(0.001)$ & $1.16(0.001)$ \\
\hline 1990 & $1.12(0.0003)$ & $1.17(0.001)$ & $1.14(0.0001)$ & $1.07(0.001)$ & $1.05(0.001)$ & $1.12(0.0005)$ \\
\hline
\end{tabular}

*Denotes statistical significance in comparison with control.

seedlings sustaining tissue removal in August 1987 averaged only $4 \mathrm{~cm}$ shorter than control seedlings. There were no other significant differences detected for height RGR. Relative height growth for tissue removal and control seedlings were comparable in 1989 and 1990.

Stem volume RGR increased from 1988 to 1989 and decreased from 1989 to 1990 for the control seedlings and seedlings that sustained tissue removal (Table 2). Significant differences were detected only in 1988; seedlings sustaining tissue removal in August 1987, April-May 1988, or 1987 and 1988 all showed reduced relative volume growth (from -21 to $-26 \%$ ) compared with control seedlings. Depressed relative volume growth was short-term (as also noted for relative height growth), bccause relative volume growth was comparable in 1989 and 1990 for control seedlings and seedlings sustaining tissue removal.

\section{Discussion}

\section{Growth Response and Management Implications}

Similar total heights and stem volumes in 1990 (year 5 of the plantation) for control seedlings and seedlings that sustained terminal tissue removal suggests that ponderosa pine recovers well from tissue removal if removal is not chronic. Analyses of height and stem volume RGR provide evidence that the RGR of seedlings sustaining terminal tissue removal is comparable to control seedlings by the second year after removal and occasionally by the year after removal. However, seasonality of terminal tissue removal apparently affects subsequent growth rates. Seedlings sustaining tissue removal after winter bud set (August in our study) were more likely to exhibit depressed RGR the next year than seedlings sustaining tissue removal before winter bud set (April and May in our study).

Several Pinus studies (Hill 1917; Pearson 1931; Cassady et al. 1955; Beveridge and Klomp 1973; Gillingham et al. 1976; Lewis 1980a, 1980b; Neilsen 1981; Sanchez-Martinez and Wagner 1994) include data or unquantified observations documenting various levels of apparent growth recovery of various pines to tissue removal. Hill (1917) remarked that if young ponderosa pines in Arizona were browsed by livestock, they possess "remarkable recuperative powers" if they are not rebrowsed. Similarly, Lewis (1980b) believed that slash pine (Pinus elliottii Engelmann) "...exhibits strong resiliency to injury and rapid recovery of growth." When browsing ceases, absolute height growth of radiata pine (Pinus radiata D. Don) seedlings in New Zealand is comparable to unbrowsed seedlings (Beveridge and Klomp 1973). Absolute height growth of slash pine seedlings subjected to removal of 75 or $100 \%$ of needles is comparable to control (no removal) seedlings by the fourth year post-treatment (Lewis 1980a) and by the third or fourth year after removal of 50 or $100 \%$ of terminal and lateral shoots (Lewis 1980b). Contrary to our findings, height loss (in comparison with control seedlings) resulting from tissue removal was not recovered (Hill 1917; Lewis $1980 \mathrm{a}, 1980 \mathrm{~b}$ ). Thus, height loss persisted for the duration of these studies, but absolute height growth comparable to control seedlings eventually was observed.

Growth responses we observed subsequent to seasonal tissue removal are substantiated morphologically by Cooperrider (1938). After browsing and growth loss on ponderosa pine, Cooperrider (1938) observed development of "substitute growth" arising from needle-bundle buds that originated between the needles of the remaining uppermost bundles, or rarely, whorl buds (located close beneath the shoot's tip of the previous year) and secondary buds in the axils of scales. Seedlings browsed early in the growing season before completion of shoot elongation produced more rapid substitute bud and shoot development compared with seedlings browsed later. This agrees with our findings. Seedlings sustaining terminal tissue removal in May 1987 produced a winter terminal bud by fall 1987 , either from a needlebundle bud and subsequent shoot, or from a whorl bud and shoot. In contrast, winter terminal buds were removed on seedlings sustaining terminal tissue removal in August 1987. In September, 1 month after removal, we observed development of whorl buds (produced in 1986) at the base of the terminal shoot stub on some seedlings. 
Greater height and stem volume in 1989 and 1990 of seedlings that sustained terminal tissue removal in 1988-compared with control seedlings-is perplexing but might be explained by 2 factors. First, 1988 removal seedlings were apparently more vigorous initially than control seedlings, because even in 1986 (year of planting) and 1987, height and stem volume were somewhat greater than control seedlings (Table 2), and height RGR was greater in 1987 compared with control seedlings. Second, as noted previously, terminal tissue removal in 1988 consisted primarily of breakage of elongating terminal shoots by cattle in April and May, before terminal winter bud set. Some elongating shoots (usually originating from whorl buds produced in 1987) escaped breakage and height growth appeared uninterrupted.

Our documentation of timing and magnitude of ponderosa pine growth response after seasonal terminal tissue removal by livestock is unique. We propose that the short-term or negligible reduced aboveground growth after terminal tissue removal by cattle has important management implications pertaining to prescribed livestock grazing for understory vegetation control on pine plantations. In the Mixed-Conifer Zone of the Cascade Range in southwestern Oregon, annual growth of conifer seedlings occurs primarily in the early growing season when soil water is available (Franklin and Dyrness 1973). Prescribed cattle grazing early in the growing season on the study site resulted in vegetation control suitable for enhancement of soil water availability to young conifer seedlings (Karl and Doescher 1993). Our research (Karl and Doescher 1993; this study) suggests that if silviculturists prescribe cattle grazing early in the growing season and terminal tissue is removed at that time by cattle, silviculturists can still achieve understory vegetation control and enhanced soil water availability without jeopardizing long-term aboveground growth of ponderosa pine. Terminal tissue removal late in the growing season or of a chronic nature however, is more likely to jeopardize aboveground growth.

We speculate that livestock removal of terminal tissue on ponderosa pine seedlings was primarily attributable to a lack of salt and trace mineral provision. We present this speculation to stimulate future research into this possible cause-effect relationship.

\section{Literature Cited}

Adams, S.N. 1975. Sheep and cattle grazing in forests: a review. J. Appl. Ecol. 12:143-152.

Beveridge, A.E. and B.K. Klomp. 1973. Grazing before planting and in young plantations, p. 68-76. In: New Zealand Forest Serv., Forest Res. Inst. Symp., Session 3.

Britton, R.J. 1988. Physiological effects of natural and artificial defoliation on the growth of young crops of lodgepole pine. Forest. 61:165-175.

Bruce, D. 1956. Effect of defoliation on growth of longleaf pine seedlings. Forest. Sci. 2:31-35.

Cassady, J.T., W. Hopkins, and L.B.Whitaker. 1955. Cattle grazing damage to pine scedlings. USDA-FS Southern Forest. Exp. Sta. Occas. Pap. 141., 14 p.

Cooperrider, C.K. 1938. Recovery processes of ponderosa pine reproduction following injury to young annual growth. Plant Physiol. 13:5-27.

Craighead, F.C. 1940. Some effects of artificial defoliation on pine and larch. J. Forest. 38:885-888.

Edenius, L., K. Danell, and R. Bergström. 1993. Impact of herbivory and competition on compensatory growth in woody plants: winter browsing by moose on Scots pine. Oikos 66:286-292.
Ericsson, A., S. Larsson, and O. Tenow. 1980. Effects of early and late season defoliation on growth and carbohydrate dynamics in Scots pine. J. Appl. Ecol. 17:747-769.

Franklin, J.F., and C.T. Dyrness. 1973. Natural vegetation of Oregon and Washington. USDA-FS Gen. Tech. Rep. PNW-8.

Froehlich, H.A., D.H. MeNabb, and F. Gaweda. 1982. Average annual precipitation, 1960-1980, in southwest Oregon. Oregon State Univ. Ext. Serv. Pub. EM 8220.

Gillingham, A.G., B.K. Klomp, and S.E. Peterson. 1976. Stock and pasture management for establishment of radiata pine in farmland, $p$. 38-51. In: Proc. New Zealand Grassl. Assoc.

Hill, R.R. 1917. Effects of grazing upon western yellow-pine reproduction in the national forests of Arizona and New Mexico. USDA Bull. No. 580 .

Hughes, R.H. 1976. Response of planted south Florida slash pine to simulated cattle damage. J. Range Manage. 29:198-201.

Johnson, D.R. 1993. Soil survey of Jackson County area, Oregon. USDA-SCS National Cooperative Soil Survey, in cooperation with USDI-BLM, USDA-FS, and Oregon Agr. Exp. Sta.

Karl, M.G. and P.S. Doescher. 1993. Regulating competition on conifer plantations with prescribed cattle grazing. Forest. Sci. 39:405-418.

Kulman, H.M. 1965. Effects of artificial defoliation of pine on subsequent shoot and needle growth. Forest. Sci. 11:90-98.

Lewis, C.F. 1980a. Simulated cattle injury to planted slash pine: defoliation. J. Range Manage. 33:345-348

Lewis, C.E. 1980b. Simulated cattle injury to planted slash pine: combinations of defoliation, browsing, and trampling. J. Range Manage. 33:340-345.

McNabb, D.H., H.A. Froehlich, and F. Gaweda. 1982. Average dryseason precipitation in southwest Oregon, May through September. Oregon State Univ. Ext. Serv. Pub. EM 8226.

Neilsen, W.A. 1981. Effect of simulated browsing on survival and growth of Pinus radiata (D. Don) seedlings. Australian Forest. Res. 11:47-53.

Pearson, G.A. 1931. Recovery of western yellow pine seedlings from injury by grazing animals. J. Forest. 29:876-894.

Radford, P.I. 1967. Growth analysis formulae-their use and abuse. Crop Sci. 7:171-175.

Rindt, C.A. 1965. A silviculturist looks at grass and grazing effects on ponderosa pine, p. 69-70. In: Proc. Soc. Amer. Forest. 1964.

Sanchez-Martinez, G. and M.R. Wagner. 1994. Sawfly (Hymenoptera: Diprionidae) and artificial defoliation affects above- and below-ground growth of ponderosa pine seedlings. J. Econ. Entomol. 87:1038-1045.

Sparhawk, W.N. 1918. Effect of grazing upon western yellow pine reproduction in central Idaho. USDA Bull. No. 738.

Tesch, S.D., O.T. Helgerson, K. Baker -Katz, and E.J. Korpela. 1990. Adaptive FIR annual report, October 1, 1989-September 30, 1990 Forest Res. Lab., Oregon State Univ., Southwest Oregon Forest. Intensified Research, Medford, Ore.

Wheeler, J.L., J.C. Burns, R.D. Mochrie, and H.D. Gross. 1973. The choice of fixed or variable stocking rates in grazing experiments. Exp. Agr. 9:289-302. 